in their requirements. Research, however, must be thorough, tested out in all its bearings, and put before farmers as a sound investment. Surveying the whole agricultural field, the leading achievements of agricultural research which have led to definite economic results are touched on, and even to those familiar with the subject the cumulative result is impressive. The problem of production has been solved. The famines predicted from time to time in the recent past are not likely to trouble us. The need for the future is to get into wider circulation the plenty which improved methods have secured.

\section{Gold and Silver Currencies}

IN a recent publication (" "Standard Gold' and Silver : the Way out of the Crisis." Pp. 88. Manchester : Taylor Garnett Evans and Co., Ltd., 1932), Dr. Ernest Zucker advocates the devaluation of the world's gold currencies by means of a onethird reduction in the gold content of the standard coins. He also advocates the introduction of silver as a subsidiary currency to facilitate trade with the silver-using East. The effect of the first proposal, he argues, would be to raise the prices of raw materials and similar commodities by about half, since their prices are world prices based on gold. The purchasing power of wages and salaries, on the other hand, would be reduced by about a third. In this way the disequilibrium between the prices of raw materials and manufactured products could be removed, while inter-allied debts and reparations would be reduced by a third. Dr. Zucker's scheme, however, presents serious difficulties. First there is the practical problem of securing common action among creditor nations, especially the United States and France. Secondly, devaluation would not in itself re-adjust the maldistribution of gold. Creditor countries would continue to attract the world's gold and if they persisted in high tariff policies, it would still be difficult for debtor countries to make payments, or for the volume of world trade to be increased.

\section{Daily Mail Ideal Home Exhibition}

THe Daily Mail Ideal Home Exhibition will be open at Olympia, London, W., on March 29-April 29. According to advance information recent developments in illumination will be utilised to ereate in the Grand Hall of Olympia, a 'Rainbow City'. The colours of a great rainbow, appearing from among 'clouds of depression', will be produced by a gigantic scheme of neon lighting, and the eye will travel back over a hall in rainbow hues to 'the sun of prosperity'. Scientific workers will be attracted by a series of "Rooms of the Scientists" on the first floor of the Empire Hall, where we are promised representations of the surroundings in which Newton, Faraday, Marconi and others carried on their investigations. A section of the Exhibition will be devoted to the home cinema, while close by will be the telephone exhibit of the General Post Office. Modern sanitation, heating and refrigeration apparatus, lighting schemes, general house equipment and labour-saving devices -indeed, everything for home service, comfort and recreation-are other and more usual features of the annual exhibition.

\section{Land Utilisation Maps}

The Land Utilisation Survey has produced through the Ordnance Survey two one-inch sheets embodying some results of its work. These are sheets 114, covering the area to the south-west of London, and 142, showing the Isle of Wight, Portsmouth and the southern part of the New Forest. They are published at $4 s$. each and the sheet lines are the same as those of the popular 'one-inch' maps. Results are reduced from the original 'six. inch' survey and printed in six colours over the topographical detail and contours of the original ordnance sheets-on which the rivers appear in blue. Dark green shows forest and woodland, light green meadowland and permanent pasture, brown arable or tilled land, including grass grown in rotation and land lying fallow at the time of survey, yellow heathland, moorland, common and rough hill pasture and purple garden allotments and orchards. Land that is agriculturally unproductive, including builtover land, quarries, yards and roads is shown in red. Private parks and golf courses have been divided according to the use made of the land for grazing or other purposes. The maps are beautifully produced and give a striking picture of the uses to which land in Great Britain is put and should prove invaluable for many purposes. It is hoped to publish further sheets in course of time.

\section{Dried Poultry Manure}

THE possibility of making better use of poultry manure is receiving considerable attention at the present time and in the Journal of the Ministry of Agriculture (vol. 39, p. 656) R. Sayee and F. Hanley give an interesting account of the production of kiln. dried poultry manure. The kiln, which is very similar to that used in maltings, is a ventilated brick building with a corrugated asbestos roof which is lined with asbestos sheeting. It is heated with an ordinary coke furnace and a system of flues. After a preliminary drying in the air for about two days, the manure is spread on the kiln floor to a depth of 7-8 in., being turned occasionally during treatment. The time required for the drying process depends on the state of the material, its depth on the floor, weather and other conditions, but 48 hours should be sufficient for average material 6-7 in. deep, the maximum temperature during the process usually approaching $300^{\circ} \mathrm{F}$. Four tons of manure may conveniently be treated at a time and will yield approximately two tons of dried material, which should not contain more than 7-10 per cent moisture if it is to store satisfactorily. Some loss of nitrogen during the drying is unavoidable, but analyses show that the final composition of the poultry manure closely resembles that of other organic fertilisers, which sell at $£ 310$ s. $-£ 5$ a ton, at present in considerable demand in market gardening districts. In addition, the constituents are present in a readily available form. 